\title{
Pengaruh ROA, CR,TATO, dan DER terhadap Harga Saham pada Sektor Pertambangan yang terdaftar di BEI Periode 2016-2019
}

\author{
Tina Novianti Sitanggang ${ }^{1}$; Cristover Halomoan Manalu ${ }^{2}$; Mutiara M. Sianturi ${ }^{3}$ \\ Universitas Prima Indonesia ${ }^{123}$ \\ tinanoviantisitanggang@gmail.com ; cristovermanalu@gmail.com ; sianturi.mutiara@gmail.com \\ *Corresponding Author \\ Submitted: 5 Mei 2021
}

Accepted: 9 Agustus 2021

Published: 2 Januari 2022

\begin{abstract}
A high share price is an achievement expected by all companies. However, the stock price always fluctuates which always changes from time to time. This study aims to see the extent of the influence of Return On Assets, Current Ratio, Total Asset Turnover, and Debt Equity Ratio on Stock Prices in Mining Sector Companies on the Indonesian Stock Exchange for the period 2016-2019. The sample selection technique in this study is purposive sampling. The analysis technique used is linear regression, while the hypothesis testing used t-test and f-test with a significance level of 5\%. The classical assumption test used is the normality test, multicollinearity test, autocorrelation test, and heteroscedasticity test. From this research, it is found that Return On Assets has a significant effect on stock prices, Current Ratio has no and significant effect on stock prices, while Total Asset Turnover and Debt Equity Ratio have no effect and are not significant to stock prices. Simultaneously there is an influence between Return On Assets, Current Ratio, Total Asset Turnover, and Debt Equity Ratio on stock prices.
\end{abstract}

Keywords: Stock Prices, Return On Assets, Current Ratio, Total Asset Turnover, and Debt Equity Ratio

\section{PENDAHULUAN}

Setiap perusahaan yang berdiri pasti memiliki alasan dan tujuan yang jelas. Salah satunya adalah untuk memperoleh laba yang sebesar - besarnya. Perusahaan yang memperoleh laba yang besar selalu menjadi daya tarik bagi investor untuk menanamkan sahamnya. Karena emiten yang dapat menghasilkan laba yang tinggi akan meningkatkan tingkat kembalian yang diperoleh investor yang tercermin dari harga saham perusahaan tersebut. Namun harga saham selalu mengalami fluktuasi yang artinya selalu mengalami perubahan dari waktu ke waktu. Terdapat beberapa faktor yang dapat mempengaruhi harga saham yaitu Return On Assets, Current Ratio, Total Asset Turnover dan Debt Equity Ratio. Perusahaan harus mampu mengukur kemampuannya dalam mengelola asset. Karena ketika nilai ROA suatu perusahaan rendah, hal itu menunjukkan bahwa perusahaan tersebut tidak mampu mengelolah aset yang dimilikinya menjadi laba . Current Ratio dapat menjelaskan bagaimana kemampuan perusahaan dalam memenuhi kewajiban lancarnya dengan aktiva lancar yang dimilikinya. Tingkat likuiditas yang tinggi dapat memberikan sinyal positif bagi investor bahwasanya perusahaan mampu menjalankan usahanya dengan baik. Total Assets Turnover mampu menunjukkan bagaimana kemampuan perusahaan dalam mengelolah aset yang dimiliki menjadi penjualan dengan maksimal. Selain tingkat Return On Asset, Current Ratio dan Total Asset Turnover penting juga untuk memperhatikan tingkat rasio hutang (Debt to Equity Ratio ) perusahaan. Setiap perusahaan pasti memiliki hutang dalam struktur modalnya. Perbedaannya terletak pada jumlah perbandingan antara hutang dengan ekuitas perusahan tersebut. Perusahaan yang memiliki nilai rasio utang yang 
tinggi menunjukkan perusahaan kurang baik dan belum mampu untuk memenuhi kewajiban jangka panjangnya .

Kusumawardani, (2010) menyimpulkan bahwa variabel DER dan ROA berpengaruh secara signifikan terhadap harga saham, sama halnya dengan penelitian Mukhtaruddin dan Romalo, (2007) pada perusahaan properti menemukan bahwa secara bersama-sama terdapat pengaruh variabel DER dan ROA terhadap harga saham. Sedangakan menurut Damanik, (2008) variabel ROA dan DER tidak memiliki pengaruh terhadap harga saham. Dalam penelitian Suwahyono, Rajio dan Oetomo, (2006) dan Wicaksono dkk (2013) menyatakan bahwa variabel TATO memiliki pengaruh positif dan signifikan terhadap harga saham.

Penelitian ini menggunakan perusahaan pertambangan yang terdaftar di Bursa Efek Indonesia. Bursa Efek Indonesia mencatat bahwa dari tahun ke tahun jumlah perusahaan pertambangan di indonesia mengalami peningkatan. Ini menunjukkan bahwa cukup banyak investor yang berminat untuk membeli saham di perusahaan sektor pertambangan di Indonesia (sumber:http://www.idx.co.id.) Melihat peningkatan perusahaan pertambangan di Indonesia, maka peneliti tertarik untuk meneliti keterkaitan antara Pengaruh Return On Assets, Current Ratio, Total Asset Turnover dan Debt Equity Ratio terhadap Harga Saham pada perusahaan pertambangan yang terdaftar di Bursa Efek Indonesia Periode 2016 2019

Adapun fenomena yang terjadi pada perusahaan pertambangan yang terdaftar di BEI yaitu pada perusahaan PT. Bumi Resources Tbk terjadi pertumbuhan laba bersih dari tahun 2016 hingga 2017 sebesar Rp.1.824.005.633.443 tetapi harga saham mengalami penurunan sebesar Rp8. Sedangkan menurut teori jika pertumbuhan laba bersih mengalami peningkatan maka harga saham akan menjadi meningkat dan sebaliknya apabila laba bersih mengalami penurunan maka dari itu harga saham akan mengalami penurunan. Pada perusahaan PT. Delta Dunia Makmur Tbk terjadi peningkatan terhadap aset lancar dari tahun 2017 hingga 2018 sebesar Rp.1.410.262.176.643 tetapi harga saham mengalami penurunan sebesar Rp. 190. Sedangkan menurut teori jika jumlah aset lancar mengalami peningkatan maka dari itu harga saham akan mengalami peningkatan dan sebaliknya apabila jumlah aset lancar mengalami penurunan maka dari itu harga saham akan mengalami penurunan. Pada perusahaan PT .Aneka Tambang Tbk terjadi penurunan jumlah hutang dari tahun 2016 hingga 2017 sebesar Rp.48,870,304,000 tetapi harga saham mengalami penurunan sebesar Rp. 270 . Sedangkan menurut teori jika jumlah hutang mengalami penurunan maka dari itu harga saham akan mengalami peningkatan dan sebaliknya apabila jumlah hutang mengalami peningkatan maka harga saham akan mengalami penurunan. (sumber:http://www.idx.co.id.)

\section{Penelitian Terdahulu}

\section{STUDI LITERATUR}

Teori Pengaruh Return On Asset Terhadap Harga Saham

Return On Asset (ROA) merupakan rasio keuangan yang digunakan untuk menilai kondisi keuangan dari suatu perusahaan dengan menggunakan skala tertentu atau suatu alat untuk menilai apakah suatu aset yang dimiliki perusahaan sudah digunakan semaksimal mungkin untuk mendapatkan keuntungan. Menurut Sitti (2016), semakin besar ROA yang dimiliki suatu perusahaan maka semakin efisien pengguna aktiva sehingga memperbesar laba. Laba yang besarakan menarik investor karena perusahaan memiliki tingkat pengembalian yang tinggi .

Teori Pengaruh Current Ratio Terhadap Harga Saham.

H1: Return On Asset berpengaruh secara parsial terhadap Harga Saham pada perusahaan Sektor Pertambangan yang terdaftar di Bursa Efek Indonesia periode 2016 - 2019.

Current Ratio merupakan rasio yang mengukur kinerja keuangan perusahaan dengan melakukan perbandingan antara aktiva lancar terhadap utang lancar suatu perusahaan. Current Ratio menunjukan sejauh mana aktiva lancar dapat menutupi 
kewajban-kewajiban lancar. Dengan perbandingan 1:1 atau 100\%. Maka semakin tinggi tingkat Current Ratio perusahaan, maka semakin baik harga saham . Riris (2017)

H2: Current Ratio berpengaruh secara parsial terhadap Harga Saham pada perusahaan Sektor Pertambangan yang terdaftar di Bursa Efek Indonesia periode 2016 - 2019.

Teori Pengaruh Total Asset Turnover Tehadap Harga Saham

Hanafi dan Halim (2010: 81) Total Asset Turnover adalah rasio menghitung efektivitas penggunaan total aktiva. Rasio yang tinggi biasanya menunjukkan manajemen yang baik, sebaliknya rasio yang rendah harus membuat manajemen mengevaluasi strategi, pemasaran, dan pengeluaran modalnya (investasi ). Total Asset Turnover( TATO ) merupakan perbandingan antara penjualan dengan total aset. Semakin tinggi nilai TATO mengartikan bahwa perputaran yang dimiliki oleh perusahaan semakin baik dan dapat dikatakan perusahaan mampu mendapatkan penjualan secara efektif dan efisien dengan total aset yang dimilikinya. Sehingga semakin tinggi nilai TATO maka investor akan semakin menyukai perusahaan tersebut dan mampu untuk menarik minat investor untuk berinvestasi pada perusahaan tersebut yang pada akhirnya akan meningkatkan harga saham perusahaan tersebut .

H3: Total Asset Turnover berpengaruh secara parsial terhadap Harga Saham pada perusahaan Sektor Pertambangan yang terdaftar di Bursa Efek Indonesia periode 2016 - 2019 .

Teori Pengaruh Debt Equity Ratio Terhadap Harga Saham

Debt Equity Ratio merupakan rasio keuangan yang membandingkan jumlah hutang dengan ekuitas yang dimiliki oleh perusahaan .Rasio ini menggambarkan sampai sejauh mana modal yang dimiliki oleh perusahaan dapat menutupi utang - utang kepada pihak luar. Menurut Rheza(2016) Debt Equity Ratio yang tinggi menandakan bahwa perusahaan tersebut memiliki jumlah hutang yang tinggi juga, dan ini juga menunjukkan bahwa ketergantungan perusahaan terhadap pembiayaan ekuitas menggunakan hutang juga tinggi. Hal ini menyebabkan investor cenderung menghindari saham perusahaan tersebut, semakin rendah permintaan dari pasar maka harga saham juga akan menurun.

H4: Debt Equity Ratio berpengaruh secara parsial terhadap Harga Saham pada perusahaan Sektor Pertambangan yang terdaftar di Bursa Efek Indonesia periode 2016 - 2019 .

\section{Persamaan Matematika}

Return On Assets

Menurut Tandelilin (2010), Return On Assets menggambarkan sejauh mana kemampuan aset aset yang dimiliki perusahaan bisa menghasilkan laba. Rasio tersebut dihitung dengan rumus :

\section{Current Ratio}

\section{Return On Assets = Laba Setelah Pajak / Total Asset}

Menurut Kasmir (2016), "Current Ratio merupakan rasio untuk mengukur kemampuan perusahaan dalam membayar kewajiban jangka pendek atau utang yang segera jatuh tempo pada saat ditagih secara keseluruhan." Current Ratio yang rendah menunjukkan bahwa likuiditas perusahaan buruk dan sebaliknya perusahaan dengan tingkat current ratio yang tinggi menunjukkan bahwa likuiditas perusahaan tersebut baik. Rasio tersebut dihitung dengan rumus:

\section{Current Ratio $=$ Aktiva Lancar $/$ Kewajiban Lancar}

Total AssetTurnover

Menurut Syamsuddin (2011), Total Asset Turnover adalah tingkat efisiensi penggunaan keseluruhan aktiva perusahaan didalam menghasilkan volume penjualan tertentu. Rasio tersebut dihitung dengan rumus : 


\section{Total Asset Turnover $=$ Penjualan Bersih $/$ Total Aset}

\section{Debt Equity Ratio}

Menurut Kasmir (2014), Debt Equity Ratio adalah rasio keuangan yang dipakai untuk menilai utang dengan ekuitas perusahaan. Dengan kata lain, seberapa besar nilai setiap rupiah modal perusahaan yang dijadikan sebagai jaminan utang. Rasio tersebut dihitung dengan rumus:

\section{Debt Equity Ratio = Total Kewajiban $/$ Total Aset}

Metodologi Penelitian

\section{METODE}

Metode penelitian yang digunakan di dalam penelitian ini merupakan metode penelitian kuantitatif . Menurut Sugiyono (2010:8), metode kuantitatif dapat diartikan sebagai metode penelitian yang berlandasan pada filsafat positivisme, digunakan untuk meneliti pada populasi atau sampel tertentu, pengumpulan data menggunakan instrumen penelitian , analisis data bersifat kuantitatif / statistik, dengan tujuan untuk menguji hipotesis yang telah ditetapkan .

Populasi

Menurut Sugiyono (2010:215), populasi diartikan sebagai wilayah generalisasi yang terdiri atas: obyek / subyek yang mempunyai kualitas dan karakteristik tertentu yang ditetapkan oleh peneliti untuk dipelajari dan kemudian ditarik kesimpulannya. Populasi penelitian ini adalah 49 perusahaan sektor pertambangan yang terdaftar di Bursa Efek Indonesia periode $2016-2019$

Sampel

Menurut Sugiyono (2012:116), sampel adalah bagian dari jumlah karakteristik yang dimiliki oleh populasi tersebut . Dalam penelitian ini, teknik sampling yang digunakan adalah purposive sampling . Menurut $\underline{\text { Sugiyono(2010:218), purposive sampling }}$ adalah teknik pengambilan sampel sumber data dengan pertimbangan tertentu . Beberapa kriteria yang ditentukan adalah :

Perusahaan Sektor Pertambangan yang terdaftar di Bursa Efek Indonesia periode 2016 2019 .

Perusahaan Sektor Pertambangan yang mempublikasikan laporan keuangannya secara lengkap selama periode 2016 - 2019.

\begin{tabular}{|l|l|l|}
\hline No. & \multicolumn{1}{|c|}{ Kriteria } & Jumlah \\
\hline 1. & $\begin{array}{l}\text { Perusahaan Sektor Pertambangan yang terdaftar di Bursa Efek Indonesia periode } \\
2016-2019 .\end{array}$ & 49 \\
\hline 2. & $\begin{array}{l}\text { Perusahaan Sektor Pertambangan yang tidak mempublikasikan laporan keuangan } \\
\text { secara lengkap selama periode 2016 - 2019. }\end{array}$ & (15) \\
\hline 3. & Perusahaan Sektor Pertambangan yang mengalami kerugian periode 2016-2019. & $(17)$ \\
\hline & \multicolumn{1}{|c|}{ Jumlah Sampel Perusahaan } & $\mathbf{1 7}$ \\
\hline & \multicolumn{1}{|c|}{ Data Observasi Penelitian 17x4 } \\
\hline
\end{tabular}

Sumber : Hasil Penelitian,2020 (Data Diolah)

\section{UJI STATISTIK DESKRIPTIF}

\section{HASIL}

Stasitik deskriptif merupakan suatu uji yang tujuannya adalah untuk mendeskriptifkan nilai minimum, maksimum, nilai rata - rata (mean) dan standar deviasi atau simpangan baku . Hasil pengelolahan data dari sampel dapat dilihat dari tabel statistik deskriptif dibawah ini 
Tabel 2.1 Statistik Deskriptif

Descriptive Statistics

\begin{tabular}{|l|r|r|r|r|r|}
\hline & $\mathrm{N}$ & \multicolumn{1}{|c|}{ Minimum } & Maximum & \multicolumn{1}{c|}{ Mean } & Std. Deviation \\
\hline ROA & 68 & 0 & 1 &, 12 &, 136 \\
CR & 68 & 0 & 9 & 2,06 & 1,471 \\
TATO & 68 & 0 & 2 &, 87 &, 484 \\
DER & 68 & 0 & 2 &, 46 &, 267 \\
Harga_Saham & 68 & 50 & 19875 & 2440,88 & 4100,239 \\
\hline
\end{tabular}

Sumber : Hasil Penelitian,2020 (Data Diolah)

Berdasarkan dari tabel diatas maka dapat dilihat bahwa nilai minimum, nilai maximum, nilai rata - rata (mean) dan standar deviasi dari Return On Assets, Current Ratio, Total Asset Turnover, Debt Equity Ratio dan Harga Saham adalah sebagai berikut :

Return On Assets (X1) dengan sampel sebanyak 68 memiliki nilai minimum 0\% dan nilai maksimum $83 \%$. Sedangkan untuk nilai rata- rata (mean) $11,54 \%$ dan untuk standar deviasi sebesar $13,633 \%$.

Current Ratio (X2) dengan sampel sebanyak 68 memiliki nilai minimum $39 \%$ dan nilai maksimum $922 \%$. Sedangkan untuk nilai rata - rata (mean) 205, $78 \%$ dan untuk standart deviasi sebesar 147, $062 \%$.

Total Asset Turnover (X3) dengan sampel sebanyak 68 memiliki nilai minimum $0 \%$ dan nilai maksimum $187 \%$. Sedangkan untuk nilai rata - rata ( mean ) $86,75 \%$ dan untuk standart deviasi sebesar $48,365 \%$.

Debt Equity Ratio (X4) dengan sampel sebanyak 68 memiliki nilai minimum $11 \%$ dan nilai maksimum $190 \%$. Sedangkan untuk nilai rata -rata ( mean ) 46, $26 \%$ dan untuk standart deviasi sebesar $26,707 \%$.

Harga Saham ( Y ) dengan sampel sebanyak 68 memiliki nilai minimum Rp50 dan nilai maksimum Rp19. 875. Sedangkan untuk nilai rata- rata ( mean ) 2440 , 88 dan untuk standart deviasi sebesar Rp4 . 100,239 .

\section{UJI ASUMSI KLASIK}

Uji Normalitas

Uji normalitas memiliki tujuan untuk menilai dan menguji apakah di dalam suatu regresi, suatu variabel berdistribusi normal atau tidak normal . Untuk mendeteksi apakah residual berdistribusi normal atau tidak yaitu dengan analisis grafik dan analisis statistik

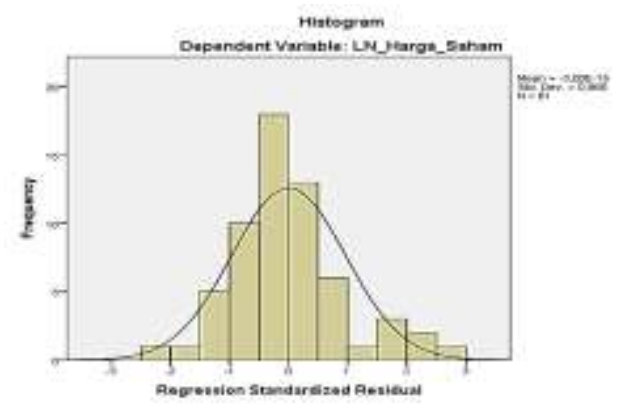

Gambar 2.1 Histogram Data

Sumber : Hasil Penelitian,2020 (Data Diolah)

Dari gambar histogram diatas menunjukkan bahwa data di dalam garis melengkung yang membentuk seperti lonceng, tidak melenceng ke kiri atau ke kanan. Maka dapat dikatakan data berdistribusikan normal dan memenuhi asumsi normalitas . 


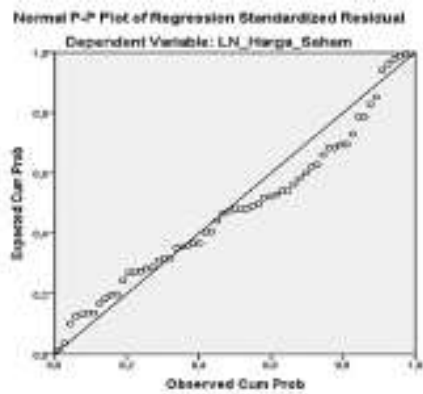

Gambar 2.2 PP-Plot

Sumber : Hasil Penelitian,2020 (Data Diolah)

Dari gambar 2 diatas menunjukkan bahwa titik - titik mendekati garis diagonal sehingga dapat disimpulkan bahwa data tersebut berdistribusi normal

Tabel 2.2 Kolmogorov Smirnov

One-Sample Kolmogorov-Smirnov Test

\begin{tabular}{|c|c|c|}
\hline & & $\begin{array}{c}\text { Unstandardized } \\
\text { Residual }\end{array}$ \\
\hline $\begin{array}{l}\text { N } \\
\text { Normal Parameters } \\
\text { Most Extreme Differences } \\
\text { Kolmogorov-Smirnov Z } \\
\text { Asymp. Sig. (2-tailed) }\end{array}$ & $\begin{array}{l}\text { Mean } \\
\text { Std. Deviation } \\
\text { Absolute } \\
\text { Positive } \\
\text { Negative }\end{array}$ & $\begin{array}{r}61 \\
0 \mathrm{E}-7 \\
1,17796902 \\
, 118 \\
, 118 \\
-, 068 \\
, 922 \\
, 363\end{array}$ \\
\hline
\end{tabular}

Sumber : Hasil Penelitian,2020 (Data Diolah)

Berdasarkan tabel $2 \mathrm{KS}$ diatas nilai sig nya di atas 0 , 05 maka dapat disimpulkan bahwa uji tersebut berdistribusi normal .

Jika nilai sig lebih kecil dari 0, 05 maka distribusi data residual tidak normal .

Jika nilai sig lebih besar dari 0 , 05 maka data residual berdistribusi normal

Uji Multikoleneritas

Tabel 2.3 Uji Multikoleneritas

\begin{tabular}{|rl|r|r|}
\hline Model & \multicolumn{2}{|c|}{ Collinearity Statistics } \\
\cline { 3 - 4 } & & Tolerance & \multicolumn{1}{c|}{ VIF } \\
\hline \multirow{2}{*}{1} & (Constant) & & \\
\cline { 2 - 4 } 1 & LN_ROA &, 795 & 1,257 \\
& LN_CR &, 602 & 1,662 \\
& LN_TATO &, 756 & 1,323 \\
& LN_DER &, 538 & 1,858 \\
\hline
\end{tabular}

Sumber : Hasil Penelitian,2020 (Data Diolah)

Dari analisis penelitian tersebut keempat variabel penelitian menunjukkan besar tolerance $>0,10$ serta besar VIF $<10$, sehingga mampu dikatakan tidak mengalami multikolonieritas .

3. Uji Autokorelasi 
Uji autokorelasi digunakan untuk mengetahui ada atau tidaknya penyimpangan asumsi klasik autokorelasi yaitu korelasi yang terjadi antara residual pada satu pengamatan dengan pengamatan lain pada model regresi .

Kriteria untuk melihat uji ini yaitu $: \mathrm{du}<\mathrm{dw}<4-\mathrm{du}$

Tabel 2.4 Uji Autokorelasi

Model Summary

\begin{tabular}{|l|r|r|r|r|r|}
\hline Model & \multicolumn{1}{|c|}{$\mathrm{R}$} & $\mathrm{R}$ Square & $\begin{array}{c}\text { Adjusted } \mathrm{R} \\
\text { Square }\end{array}$ & $\begin{array}{c}\text { Std. Error of the } \\
\text { Estimate }\end{array}$ & Durbin-Watson \\
\hline 1 &, $562^{\mathrm{a}}$ &, 316 &, 267 & 1,21980 & 1,883 \\
\hline
\end{tabular}

a. Predictors: (Constant), LN_DER, LN_ROA, LN_TATO, LN_CR

b. Dependent Variable: LN_Harga_Saham

\section{Sumber : Hasil Penelitian,2020 (Data Diolah)}

Dari hasil uji autokorelasi nilai DW, membuktikan jumlah DW sebesar 1,883 . Dengan jumlah du sebanyak 1, 7671. Maka jumlah $\mathrm{du}<\mathrm{dw}<4-\mathrm{du}$ atau 1,7671 $<1,883<2,2329$ sehingga hasil tersebut tidak mengalami autokorelasi .

Uji Heterokedastisitas

Uji heterokedastisitas bertujuan untuk menguji apakah dalam model regresi terjadi ketidaksamaan varian dari residual dalam satu pengamatan ke pengamatan lain. Uji heterokedastisitas dapat ditunjukkan dalam grafik scatterplot dan uji gletser .

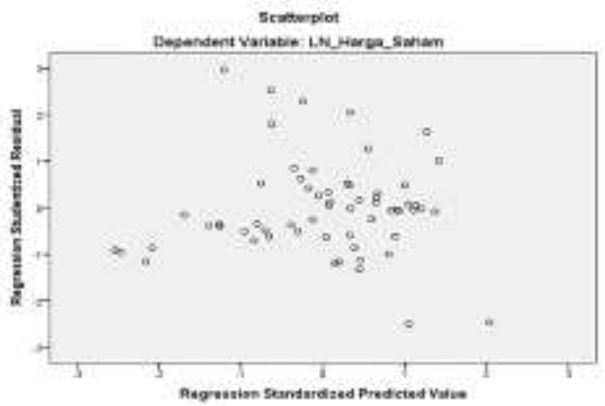

Gambar 2.3 Uji Heterokedastisitas

Sumber : Hasil Penelitian,2020 (Data Diolah)

Pada gambar diatas terlihat bahwa titik - titik tersebar dan tidak ada berkumpul dalam satu titik, maka grafik scatterplot disimpulkan tidak mengalami heterokedastisitas

Tabel 2.5 Uji Gletser

Coefficients $^{\mathrm{a}}$

\begin{tabular}{|c|c|c|c|c|c|c|}
\hline \multirow{2}{*}{\multicolumn{2}{|c|}{ Model }} & \multicolumn{2}{|c|}{ Unstandardized Coefficients } & \multirow{2}{*}{$\begin{array}{c}\begin{array}{c}\text { Standardized } \\
\text { Coefficients }\end{array} \\
\text { Beta }\end{array}$} & \multirow[t]{2}{*}{$\mathrm{T}$} & \multirow[t]{2}{*}{ Sig. } \\
\hline & & B & Std. Error & & & \\
\hline \multirow{5}{*}{1} & (Constant) & ,726 & ,240 & & 3,027 & ,004 \\
\hline & LN_ROA & ,064 & ,071 & 133 & 905 & ,369 \\
\hline & LN_CR &,- 135 & , 135 &,- 169 & $-1,000$ & ,322 \\
\hline & LN_TATO &,- 075 & 080 &,- 141 &,- 938 & ,352 \\
\hline & LN_DER &,- 030 & , 159 &,- 034 &,- 190 & ,850 \\
\hline
\end{tabular}

a. Dependent Variable: Abs_RES

Sumber : Hasil Penelitian,2020 (Data Diolah)

Dari tabel di atas mengatakan nilai signifikan untuk variabel Return On Assets sebesar 0, 369, variabel Current Ratio sebesar 0, 322, variabel Total Asset Turnover sebesar 0,352, dan variabel Debt Equity Ratio sebesar 0,850 melebihi 0, 05, dengan ini data tersebut terhindar dari heterokedastisitas .

Dari analisis penelitian uji analisis regresi linear berganda diperoleh hasil:

$\mathrm{LN}$ Harga Saham $=9,008+0,792 \mathrm{ROA}+0,587 \mathrm{CR}-0,278 \mathrm{TATO}+0,468$ DER

Dari persamaan regresi linear berganda tersebut: 
Nilai konstanta ( a ) mengatakan jika variabel Return On Assets, Current Ratio, Total Asset Turnover, dan Debt Equity Ratio dianggap 0, maka Harga Saham pada Sektor Pertambangan yang terdaftar di BEI sebesar 9, 008 .

Koefisien regresi Return On Assets mengatakan setiap kenaikan variabel Return On Assets sebesar $1 \%$ akan menyebabkan kenaikan nilai Harga Saham sebesar 0, 792 dengan anggapan variabel independen adalah nol .

Koefisen regresi Current Ratio mengatakan setiap kenaikan variabel Current Ratio sebesar $1 \%$ akan menyebabkan kenaikan nilai Harga Saham sebesar 0, 587 dengan anggapan variabel independen adalah nol.

Koefisen regresi Total Asset Turnover mengatakan setiap kenaikan variabel Total Asset Turnover sebesar $1 \%$ akan menyebabkan penurunan nilai Harga Saham sebesar - 0, 278 dengan anggapan variabel independen adalah nol .

Koefisen regresi Debt Equity Ratio mengatakan setiap kenaikan variabel Debt Equity Ratio sebesar $1 \%$ akan menyebabkan kenaikan nilai Harga Saham sebesar 0, 468 dengan anggapan variabel independen adalah nol.

Pengujian Hipotesis Secara Simultan (Uji F)

Uji hipotesis secara simultan ( Uji F) digunakan untuk mengetahui seberapa jauh pengaruh variabel independen terhadap variabel dependen secara simultan atau secara keseluruhan. Hasilnya adalah sebagai berikut:

\begin{tabular}{|c|c|c|c|c|c|c|}
\hline \multicolumn{7}{|c|}{$\begin{array}{c}\text { Tabel } 2.7 \text { Uji F } \\
\text { ANOVA }^{\mathrm{a}}\end{array}$} \\
\hline Model & & Sum of Squares & $\mathrm{df}$ & Mean Square & $\mathrm{F}$ & Sig. \\
\hline \multirow{3}{*}{1} & Regression & 38,382 & 4 & \multirow{3}{*}{$\begin{array}{l}9,595 \\
1,487\end{array}$} & \multirow[t]{3}{*}{6,454} & \multirow[t]{3}{*}{, $000^{\circ}$} \\
\hline & Residual & 83,257 & 56 & & & \\
\hline & Total & 121,639 & 60 & & & \\
\hline
\end{tabular}

Dari keterangan tabel menunjukkan nilai $\mathrm{F}_{\text {hitung }} 6,454$ dengan tingkat signifikan 0 , 000 . Sedangkan $\mathrm{F}_{\text {tabel }}$ 2, 54 dengan nilai signifikansi 0,05 . Hal ini menunjukkan bahwa $\mathrm{F}_{\text {hitung }}>\mathrm{F}_{\text {tabel }}$ atau 6, 454 $>2,54$ dan probabilitas signifikansi $0,000<0,05$, sehingga disimpulkam hipotesis diterima, maka Return On Assets, Current Ratio, Total Asset Turnover dan Debt Equity Ratio memiliki pengaruh secara simultan terhadap Harga Saham .

Pengujian Hipotesis Secara Parsial (Uji T)

Uji T pada dasarnya untuk mengetahui pengaruh masing - masing variabel independen terhadap variabel dependen .

Tabel 2.8 Uji T

Coefficients $^{\mathrm{a}}$

\begin{tabular}{|c|c|c|c|c|c|c|}
\hline \multirow{2}{*}{\multicolumn{2}{|c|}{ Model }} & \multicolumn{2}{|c|}{ Unstandardized Coefficients } & Standardized & \multirow[t]{2}{*}{$\mathrm{t}$} & \multirow[t]{2}{*}{ Sig. } \\
\hline & & $B$ & Std. Error & Beta & & \\
\hline \multirow{5}{*}{1} & (Constant) & 9,008 & ,604 & & 14,918 & , 000 \\
\hline & LN_ROA & 792 & , 178 & ,552 & 4,456 & ,000 \\
\hline & LN_CR &, 587 & ,340 & ,246 & 1,725 & 090 \\
\hline & LN_TATO &,- 278 & 201 &,- 176 & $-1,381$ & 173 \\
\hline & LN_DER & ,468 & ,401 & ,176 & 1,169 & 247 \\
\hline
\end{tabular}


a. Dependent Variable: LN_Harga_Saham

Sumber : Hasil Penelitian,2020 (Data Diolah)

Dari tabel, nilai $\mathrm{T}_{\text {tabel }}$ untuk signifikansi 0,05 pada derajat bebas 56 adalah 2, 00324 . Dengan demikian hasil Uji T sebagai berikut:

Hasil perhitungan Uji T untuk variabel Return On Assets secara parsial diperoleh nilai $t_{\text {hitung }} 4,456$ dengan nilai signifikan 0,000 maka $t_{\text {hitung }}>t_{\text {tabel }}$ atau $4,456>2,00324$ dengan signifikan $0,000<0,05$ dengan kriteria Ho ditolak dan Ha diterima yang artinya Return On Assets berpengaruh signifikan terhadap Harga Saham pada Sektor Perambangan yang terdaftar di BEI periode 2016 - 2019.

Hasil perhitungan Uji T untuk variabel Current Ratio secara parsial diperoleh nilai $t_{\text {hitung }} 1,725$ dengan nilai signifikan 0,000 maka $t_{\text {hitung }}<t_{\text {tabel }}$ atau $1,725<2,00324$ dengan signifikan $0,000<0,05$ dengan kriteria Ho diterima dan Ha ditolak yang artinya Current Ratio tidak berpengaruh dan signifikan terhadap Harga Saham pada Sektor Perambangan yang terdaftar di BEI periode 2016 - 2019.

Hasil perhitungan Uji $\mathrm{T}$ untuk variabel Total Asset Turnover secara parsial diperoleh nilai $\mathrm{t}_{\text {hitung }}-1,381$ dengan nilai signifikan 0,173 maka $-\mathrm{t}_{\text {hitung }}<\mathrm{t}_{\text {tabel }}$ atau -1 , $381<2$, 00324 dengan signifikan $0,173>0,05$ dengan kriteria Ho diterima dan Ha ditolak yang artinya Total Asset Turnover tidak berpengaruh dan tidak signifikan terhadap Harga Saham pada Sektor Perambangan yang terdaftar di BEI periode 2016 - 2019.

Hasil perhitungan Uji T untuk variabel Debt Equity Ratio secara parsial diperoleh nilai $t_{\text {hitung }} 1,169$ dengan nilai signifikan 0,247 maka $t_{\text {hitung }}<t_{\text {tabel }}$ atau $1,169<2$, 00324 dengan signifikan $0,247>0,05$ dengan kriteria Ho diterima dan Ha ditolak yang artinya Debt Equity Ratio tidak berpengaruh dan tidak signifikan terhadap Harga Saham pada Sektor Perambangan yang terdaftar di BEI periode 2016 - 2019.

\section{Analisis Koefisien Determinasi $\left(\mathbf{R}^{2}\right)$}

Nilai koefisien determinasi digunakan untuk mengukur seberapa besar Return On Assets, Current Ratio, Total Asset Turnover dan Debt Equity Ratio terhadap Harga Saham Pada Perusahaaan Sektor Pertambangan yang Terdaftar di BEI periode 2016 - 2019. Berikut adalah nilai dari koefisien dari nilai determinasi .

\section{Tabel 2.9 Uji Koefisien Determinasi}

Model Summary

\begin{tabular}{|c|c|c|c|c|}
\hline Model & $R$ & R Square & $\begin{array}{l}\text { Adjusted R } \\
\text { Square }\end{array}$ & $\begin{array}{c}\text { Std. Error of the } \\
\text { Estimate }\end{array}$ \\
\hline 1 &, $562^{a}$ & ,316 & ,267 & 1,21931 \\
\hline
\end{tabular}

Sumber : Hasil Penelitian,2020 (Data Diolah)

Dari tabel diatas terlihat bahwa nilai Adjusted R Square sebesar 0,267 . Hal ini berarti 26, $7 \%$ dari variabel dependen yang dijelaskan oleh variabel independen, sedangkan sisanya $73,3 \%$ dijelaskan oleh variabel lainnya diluar dari variabel yang diteliti misalnya Gross Profit Margin .

\section{PEMBAHASAN}

Pengaruh Return On Assets terhadap Harga Saham

Berdasarkan Hasil Uji (t) diperoleh bahwa $\mathrm{t}_{\text {hitung }}>\mathrm{t}_{\text {tabel }}$ atau 4, 456 $>2,00324$ dan nilai sig lebih kecil dari 0, 05 maka hasil pengujian ini mengatakan secara parsial Return On Assets berpengaruh signifikan terhadap Harga Saham pada Perusahaan Sektor Pertambangan yang terdaftar di BEI periode 2016 - 2019. Dengan hasil seperti itu maka dapat dikatakan bahwasannya para investor melihat bagaimana cara perusahaan memaksimalkan penggunaan aset untuk menghasilkan keuntungan . 
Hasil penelitian ini sependapat dengan Maria (2020) yaitu Return On Assets secara parsial berpengaruh signifikan terhadap Harga Saham pada Perusahaan Manufaktur yang terdaftar di BEI.

\section{Pengaruh Current Ratio Terhadap Harga Saham}

Berdasarkan Hasil Uji (t) diperoleh bahwa $t_{\text {hitung }}<t_{\text {tabel }}$ atau $1,725<2$, 00324 dan nilai sig lebih kecil dari 0, 05 maka hasil pengujian ini mengatakan secara parsial Current Ratio tidak berpengaruh dan signifikan terhadap Harga Saham pada Perusahaan Sektor Pertambangan yang terdaftar di BEI periode 2016 - 2019. Tingkat Current Ratio yang tinggi dapat mendorong kualitas harga saham perusahaan. Namun dalam hal ini beberapa investor menganggap bahwa kondisi tersebut menyebabkan banyak dana perusahaan yang menganggur yang akhirnya akan mengurangi kemampuan perusahaan untuk mendapatkan laba.

Hasil penelitian ini sependapat dengan Adriana (2016) yaitu Current Ratio tidak berpengaruh signifikan terdahap Harga Saham pada Index LQ 45 di BEI .

\section{Pengaruh Total Asset Turnover Terhadap Harga Saham}

Berdasarkan Hasil Uji $(\mathrm{t})$ diperoleh bahwa $\mathrm{t}_{\text {hitung }}<\mathrm{t}_{\text {tabel }}$ atau $1,169<2,00324$ dan nilai sig lebih besar dari 0 , 05 maka hasil pengujian ini mengatakan secara parsial Total Asset Turnover tidak berpengaruh dan tidak signifikan terhadap Harga Saham pada Perusahaan Sektor Pertambangan yang terdaftar di BEI periode 2016 - 2019. Dalam hal ini artinya perusahaan memiliki total aset yang berlebihan dimana total aset yang ada tersebut belum dimanfaatkan secara maksimal untuk menciptakan penjualan .

Hasil penelitian ini tidak sependapat dengan Aldiansyah, et. all(2013) yaitu Total Asset Turnover memiliki pengaruh terhadap Harga Saham pada Perusahaan BUMN (NON - BANK ) yang Terdaftar di BEI .

\section{Pengaruh Debt Equity Ratio Terhadap Harga Saham}

Berdasarkan Hasil Uji $(\mathrm{t})$ diperoleh bahwa $\mathrm{t}_{\text {hitung }}<\mathrm{t}_{\text {tabel }}$ atau 1, $169<2,00324$ dan dengan nilai sig lebih besar dari 0, 05 maka hasil pengujian ini mengatakan secara parsial Debt Equity Ratio tidak berpengaruh dan tidak signifikan terhadap Harga Saham pada Sektor Perambangan yang terdaftar di BEI periode 2016 - 2019. Rasio ini menggambarkakn sampai sejauh mana modal yang dimiliki oleh perusahaan dapat menutupi utang - utang kepada pihak luar

Hasil penelitian ini sependapat dengan Asep et. all (2016) yaitu Debt Equity Ratio secara parsial tidak berpengaruh terhadap Harga Saham pada Perusahaan Sub Sektor Semen yang terdaftar di BEI .

\section{KESIMPULAN}

Berdasarkan hasil penelitian ini, maka kesimpulan yang ditarik yaitu Return On Assets berpengaruh signifikan terhadap Harga Saham . Current Ratio tidak berpengaruh dan signifikan terhadap Harga Saham .Total Asset Turnovertidak berpengaruh dan tidak signifikan terhadap Harga Saham. Debt Equity Ratio tidak berpengaruh dan tidak signifikan terhadap Harga Saham. Secara simultan Return On Assets, Current Ratio, Total Asset Turnover dan Debt Equity Ratio memiliki pengaruh terhadap Harga Saham .

\section{REFERENSI}

Kundiman, A. (2016). Pengaruh Current Ratio, Debt To Equity Ratio, Return On Asset, Return On Equity Terhadap Harga Saham Pada Indeks Lq 45 Di Bei Periode 2010-2014 (18 ed., Vol. 9). Among Makarti.

Putra, A. C. (2013). Pengaruh Kinerja Keuangan Terhadap Harga Saham P Ada Perusahaan Bumn (Non-Bank) Yang Terdaftar Di Bursa Efekindonesia. Diponegoro Journal Of Social And Politic, 1-9. 
Alipudin, A. (2016). Pengaruh EPS, ROE, ROA Dan DER Terhadap Harga Saham Pada Perusahaan Sub Sektor Semen Yang Terdaftar Di BEI. Jurnal Ilmiah Akuntansi Fakultas Ekonomi, 2, 1-22.

Hanafi, M. M., \& Halim, A. (2010). Analisis Laporan Keuangan. Yogyakarta: UPP AMP YKPN. Kasmir, K. (2010). Pengantar Manajemen Keuangan. Jakarta: Kencana Prenada Media Group.

Kasmir, K. (2014). Analisis Laporan Keuangan (7 ed.). Jakarta: PT. Raja Grafindo Persada.

Kasmir, K. (2016). Analisis Laporan Keuangan . Jakarta: Rajawali Pers.

Kusumawardani, A. (2010). Analisis Pengaruh EPS, PER, ROE, FL, DER, CR, ROA Pada Harga Saham Dan Dampaknya Terhadap Kinerja Perusahaan LQ45 Yangterdaftar Di BEI Periode 2005-2009. Jakarta: Universitas Gunadarma.

Maria, B. P. (2020). Pengaruh Return On Asset (ROA), Earning Per Share (EPS), Dan Return On Equity (ROE) Terhadap Harga Saham. Yogyakarta: Universitas Sanata Dharma.

Mukhtaruddin., \& Desmoon, K. R. (2007). Pengaruh Return On Assets (ROA),Return On Equity (ROE), Return On Investment (ROI), Debt To Equity Ratio (DER) dan Book Value Per Share Terhadap Harga Saham Properti Di BEJ. Jurnal Penelitian dan Pengembangan Akuntansi, 1, 69-77.

Rajio, S., \& Hening, W. O. (2006). Analisis Pengaruh Beberapa Variabel Fundamental Keuangan Perusahaan Terhadap Harga Saham Perusahaan Telekomunikasi Yang Tercatat Di Bursa Efek Jakarta. Ekuitas, 10, 307 - 334.

Reza. (2016). Pengaruh EPS, PER, DER, ROE Dan MVA Terhadap Harga Saham. Semarang: Universitas Dian Nuswantoro.

Riris. (2017). Pengaruh Current Ratio (CR),Debt To Equity Ratio (DER),Return On Assets (ROA),dan Return On Equity (ROE) Terhadap Harga Saham Sub Sektor Telekomunikasi. Semarang: Universitas Diponegoro.

Sitti, S. B. (2016). Pengaruh ROA, ROE, Dan EPS Terhadap Harga Saham PT Unilever Indonesia Tbk (Periode 2007-2014). Makasar: UIN Alauddin.

Sugiyono. (2010). Metode Penelitian Pendidikan Pendekatan Kuantitatif, kualitatif, dan R\&D. Bandung: Alfabeta.

Sugiyono. (2012). Memahami Penelitian Kualitatif. Bandung: Alfabeta.

Syamsuddin, L. (2011). Managemen Keuangan Perusahaan (Baru ed.). Jakarta: PT.Raja Grafindo Persada.

Tandelilin, E. (2010). Portofolio Dan Investasi Teori Dan Aplikasi (1 ed.). Yogyakarta: Kasinius. V.Damanik, M. (2008). Pengaruh Economic Value Added (EVA) Dan Analisis Fundamental Terhadap Harga Saham (Studi Pada Sektor Industri Perdagangan Retail). Universitas Gunadarma.

Wicaksono, H. A. (2013). Pengaruh Current Ratio, Debt to Assets Ratio, Total Assets Turnover, Return On Equity, Suku Bunga, Kurs Valuta Asing, Inflasi, dan Kas Dividen Terhadap Harga Saham. Yogyakarta: Universitas Negeri Yogyakarta. 